\title{
ANALYSIS OF RURAL FARM HOUSEHOLDS' ACCESS TO FORMAL AGRICULTURAL CREDIT IN YOLA SOUTH LOCAL GOVERNMENT AREA, ADAMAWA STATE, NIGERIA
}

\author{
Amurtiya Michael ${ }^{1}$, Yuniyus Dengle Giroh ${ }^{1}$, \\ Mark Polycarp ${ }^{1}$, Zubairu Emmanuel Ashindo ${ }^{2}$ \\ ${ }^{1}$ Department of Agricultural Economics and Extension, Modibbo Adama University of Technology, PMB 2076, \\ Yola, Nigeria \\ ${ }^{2}$ Department of Agricultural Economics and Extension, Taraba State University, Jalingo, Nigeria
}

\begin{abstract}
MICHAEL AMURTIYA, GIROH DENGLE YUNIYUS, POLYCARP MARK, ASHINDO ZUBAIRU EMMANUEL. 2018. Analysis Of Rural Farm Households' Access To Formal Agricultural Credit In Yola South Local Government Area, Adamawa State, Nigeria. Acta Universitatis Agriculturae et Silviculturae Mendelianae Brunensis, 66(4): 947-954.

The purpose of this study was to analyse rural farm households' access to formal agricultural credit in Yola South Local Government Area of Adamawa state, Nigeria. Descriptive and inferential statistics were used to analyse the primary data collected using structured questionnaire (from 140 rural farming households). Findings from the study have shown that, $90 \%$ of the respondents were male, mostly educated $(70 \%)$ and married (89\%) engaging in farming as their primary livelihood activity (about $81 \%$ ) with an average farm size of 2.47 hectares. The result of the binary logit regression has shown that level of education and income do influence access to credit positively, while age and distance to access point negatively influence respondents' access to formal credit. The study further revealed that, lack of acceptable collateral/security, high interest rates, low financial literacy, and complex banking procedures were the main factors that limits the respondents' access to credit facility from formal sources. In order for farmers to have an improved access to formal credits, the formation of strong groups that are viable to provide the needed capital is encouraged, banking operations should be simplified to suite farmers' needs/convenience and financial literacy among farmers should be improved through awareness campaigns (in agricultural extension packages).
\end{abstract}

Keywords: access, formal agricultural credit, rural, farm-households, farmers, Adamawa state, Nigeria

\section{INTRODUCTION}

Nigeria's rural space is home to over 93 million people who mostly depend on agriculture for their livelihoods (World Bank, 2014). In recent decades, the financial requirements of agriculture related activities have increased tremendously due to the extended use of modern farm inputs and mechanization (Bashir et al., 2010). But, these rural residents constitute bulk of the people trapped in the poverty web (Adepoju and Yusuf, 2012). In Adamawa State for instance, a large proportion
(74.2\%) of the residents of the State live in poverty, especially those in rural areas (National Bureau of Statistics, 2014). One major way to drastically reduce poverty and improve the poor welfare situation of the rural farmers is to increase their agricultural productivity (Foltz, 2004; Awotide et al., 2015). Agricultural credit is primarily seen as a tool to increase agricultural output and productivity (especially when provide in good time), through improved adoption of new technologies and use of optimum farm inputs (Foltz, 2004; Bashir et al., 2010; Chandio et al., 2016). This is because when 
liquidity is a binding constraint, the amounts and combinations of inputs used by a farmer may deviate from optimal levels that in turn limit optimum production. Credits serves as a catalyst that activates other factors of production and makes under-used capacities functional for increased production (Ijere, 1998). Hence, enhanced access to agricultural credit by rural farmers can expedite economic growth and development of rural areas. Nwankwo (2013) defined credits as borrowed resources (mostly monies) with explicit terms for refund.

Literature is replete with studies carried out across the globe that highlights the importance of credit in enhancing agricultural production and productivity (Feder et al., 1990; Foltz, 2004; Chaovanapoonphol et al., 2005; Bashir et al., 2010; Nimoh et al., 2011; Baffoe et al., 2015; Awotide et al., 2015; Chandio et al., 2016; Anang et al., 2016; Owusu, 2017). According to Feder et al. (1990), access to credit contributes to increased productivity by bringing input levels closer to the optimal levels, thereby increasing output and productivity in China. Similarly, Chaovanapoonphol et al. (2005) portrayed the key role of agricultural credit in technical efficiency and productivity of farm households in the Upper North of Thailand. According to their findings, credit raises both the technical and allocative efficiency of agricultural production. Bashir et al. (2010) studied the impact of agricultural credit on productivity of wheat crop in Lahore, Pakistan. Based on their result, wheat yield will increase as the amount of credit increases. Similarly, Nimoh et al. (2011) used net income to analyse the effect of formal credit on the performance of the poultry industry in Kumasi, Ghana. Findings of the study revealed that there was a statistically significant difference between the net income of large poultry farmers who used credit and those who did not. Also, Baffoe et al. (2015) conducted a study to establish the relationship between access to credit and agricultural productivity in Ghana. The study established a statistically significant difference between the productivity of borrowers (higher productivity) and non-borrowers which could be attributed to the technical efficiency of borrowers. Awotide et al. (2015) examined the impact of access to credit on agricultural productivity of cassava farmers in Nigeria. The study showed that access to credit has a significant positive impact on cassava productivity. In the same vein, Chandio et al. (2016) using the OLS method showed that formal agricultural credit has positive and significant impact on agricultural output. Similarly, Anang et al. (2016) compared the technical efficiency of smallholder rice farmers with and without credit in northern Ghana using data from a farm household survey. They reported a higher level of efficiency among farmers with credit compared to those without it.

Across Nigeria, smallholder farmers access agricultural finance or credit through a number of channels. Badiru (2010) broadly categorized these credit institutions into three groups:

- Formal institutions: These are institutions that provide formal financial services. Formal financial service providers are registered companies that are licensed to offer financial services by a central monetary authority (Ghate, 1992). Formal institutions provide much more production loans than other institutions. Examples of such service providers are institutions like the commercial banks, microfinance banks, the Nigeria Bank of Agricultural (BOA), and state government-owned credit institutions;

- Semi-formal institutions: These are institutions that are registered to provide financial services and are not controlled by a central monetary authority eg. Non-Governmental Organizations (NGOs), cooperative societies etc.

- Informal institutions: These institutions render financial services outside the regulated monetary system and it includes the activities of intermediaries such as relatives and friends, traders, credit associations and money lenders (Kashuliza et al. 1998). However, informal finance may not be conducive for production activities owing to its expensive nature, short duration of availing credit, and inadequacy of funds to finance large scale production demands.

In Nigeria, there are about 37 million financially excluded adults in the country (Enhancing Financial Innovation and Access, 2014). Noteworthy is the fact that, rural farmers are the most excluded segment of the population in terms of access to formal loans (Ediomo-Ubong and Iboro, 2010; Odoemenem and Obinne, 2010; Akinbode, 2013). This is because financial institutions rate these poor farmers as risky borrowers on account of their lack of suitable collateral (Aigbokhan and Asemota, 2011). Enyim et al. (2013) and Nwankwo (2013) opined that poor credit supply is one of the factors responsible for the poor performance of the agricultural sector in Nigeria.

Over the years, the Nigerian government has clearly shown interest and made effort to improve access to finance by rural farmers. This is evident by the establishment of many institutions, programmes and schemes aimed at meeting the financial needs of the rural farmers. Notable among such laudable initiatives were; the Nigerian Agricultural, Cooperative and Rural Development Bank (NACRDB) now Bank of Agriculture (BOA) established since 1972; the Rural banking programme (operational between 1977 and 1991); Agricultural Credit Guarantee Scheme Fund (ACGSF), operational since 1978 till date; and the Nigerian Agricultural Insurance Corporation (NAIC) which has been operational since 1987. In recent past, such programmes included the Microfinance Institutions (operational since 2005 to date), the Agricultural Credit Support Scheme (ACSS) in 2006 and the Commercial Agricultural Credit Scheme (CACS) in 2009. Despite 
the proliferation of efforts geared towards improving rural farmers' access to production credit, a large proportion of Nigerian farmers still lack access to credit from formal financial institutions.

Against this backdrop, therefore, this study sought to analyse the level of access to formal agricultural credit (production credit) by rural farming households in the study area and provide information to rural development actors on appropriate measures that could be adopted to improve rural farmers' access to formal credit. The specific objectives of the study were to;

- describe the socio-economic characteristics of the rural farmers

- examine the factors affecting access to credit by the rural farmers and

- identify constraints faced by rural farmers in credit acquisition.

\section{MATERIALS AND METHODS}

\section{Study area}

The study was conducted in Yola-South Local Government Area of Adamawa State, Nigeria. The study area lies between Latitude $9^{\circ} 14^{\prime}$ North of the Equator and Longitude $12^{\circ} 28^{\prime}$ East of the Greenwich Meridian, having an average elevation of about $192 \mathrm{~m}$ (Adebayo 1999). The area falls within the Northern Guinea Savannah Zone and has a tropical wet and dry climate. Dry season lasts for a minimum of five months (November-March) while the wet season spans April to October. Mean annual rainfall is about $700 \mathrm{~mm}$ (Adebayo et al., 2012). The area has a land mass of 2,310.05 $\mathrm{km}^{2}$ and a population of 196, 197 (National Population Commission, 2006). The area is bounded by Girei to the North, Fufore to the East and Demsa to the West. The main economic activity of the inhabitants is agriculture.

\section{Sampling procedure and sample size}

Multi-stage sampling technique was employed in selecting the representative households used for this study. All the rural wards in the study area were purposively selected in the first stage. In the second stage, twelve (12) rural communities were proportionately sampled from the wards selected. a total of 140 respondents were randomly selected across the communities from the list of registered farmers obtained from the Federal Department of Agriculture, Yola, Adamawa State. The respondents were farmers who had applied for credit facility from formal financial institutions in the area in the last one year from the time of conducting the survey.

\section{Sources of data and instrument for data collection}

Data for the study were collected from primary sources using structured questionnaire administered to the selected respondents through scheduled interviews conducted individually. The instrument was validated by experts after which a pilot test was conducted on a subset of the study population to ensure that the study objectives were achieved. The data collected covers the socio-economic characteristics of the respondents, factors affecting the respondents' access to credit and their constraints to agricultural credit acquisition

\section{Data analysis}

Both descriptive and inferential statistic were used to analyse the data collected for this study. Descriptive statistical tools were used to analyse the socio-economic characteristics of the farmers; a four-point Likert-type scale was used to identify the respondents' constraints to credit acquisition. The Likert scale was coded and used for the study as: Strongly agree (4), Agree (3), Disagree (2), and strongly disagree (1). Binary Logit Regression Model was used to examine the determinants of households' access to agricultural credit in the study area. Access to credit by household heads was conceptualized as bivariate, taking the value of 1 for households with access in the last one year and 0 for lack of access in the same period. This was used as the dependent variable. Socio-economic variables as well as other indicator variables were used as independent variable and specified explicitly in the model as:

$Y=\beta_{0}+\beta_{1} X_{1}+\beta_{2} X_{2}+\beta_{3} X_{3}+\beta_{4} X_{4}+\beta_{5} X_{5}+\beta_{6} X_{6}+U$

Where;

$\mathrm{Y}=$ Access to Formal Credit $(1=$ Yes, $0=$ otherwise $)$

$\beta_{0}=$ Constant

$\mathrm{X}_{1}=$ Age of the household head (years)

$\mathrm{X}_{2}=$ Gender of the household head (Male $=1:$ Female $=0)$.

$\mathrm{X}_{3}=$ Educational status of the household head (Number of years).

$\mathrm{X}_{4}=$ Distance (Kilometres)

$\mathrm{X}_{5}=$ Membership of cooperatives (Yes $=1: \mathrm{No}=0$ )

$\mathrm{X}_{6}=$ Annual Income (Amount in Naira).

$\mathrm{U}=$ Error term

\section{RESULTS AND DISCUSSION}

\section{Respondent's socio-economic characteristics}

Respondents' socio-economic characteristics are presented in Tab. I. The Tabel showed that majority of the respondents were male $(90 \%)$ due to homogeneity in their cultural and religious practices. The mean age was 41.39 years, and there were more married household heads (88.57\%) than those divorced/widowed (11.43\%). The average household size in the study area was 7 which is relatively large. Meanwhile, distribution of household heads by education revealed that majority of them had one form of education or the other (70\%). About $96.42 \%$ of household heads interviewed were small scale farmers who cultivate between 1-5 hectares of land. 


\section{Respondent's Access to Formal Production Credit}

The respondents' access to formal production credit is presented in Tab. II. The result revealed that, $87.14 \%$ of the households had not accessed any formal credit from financial institutions in the last 12 months, only $12.86 \%$ had access to the facility. Considering the encouragement given to financial institutions by the government to improve credit access by rural farmers, access to formal credit by the respondents is very low.
Among farmers who had access to credit facility (in Tab. 2), majority (72.22\%) patronized Microfinance Banks, $16.67 \%$ got theirs from Bank of Agriculture (BOA), while $11.11 \%$ accessed the facility from Commercial Banks (as presented in Tab. III).

\section{Determinants of Credit Access}

The determinants of the respondents' access to formal production credit is presented in Tab. IV. The Binary logit model has a McFadden R-square of 0.729 which implies that about $73 \%$ of the likelihood of a respondent to secure formal credit is strongly

I: Socio-Economic Characteristics of the Respondents $(\mathbf{N}=\mathbf{1 4 0})$

\begin{tabular}{|c|c|c|}
\hline Variable & Frequency & Percentage \\
\hline \multicolumn{3}{|l|}{ Age (Years) } \\
\hline $20-29$ & 12 & 8.57 \\
\hline $30-39$ & 51 & 36.43 \\
\hline $40-49$ & 40 & 28.57 \\
\hline $50-59$ & 29 & 20.71 \\
\hline 60 and Above & 8 & 5.72 \\
\hline \multicolumn{3}{|l|}{ Mean = 41.39 Years } \\
\hline \multicolumn{3}{|l|}{ Sex } \\
\hline Male & 126 & 90.0 \\
\hline Female & 14 & 10.0 \\
\hline \multicolumn{3}{|l|}{ Marital Status } \\
\hline Married & 124 & 88.57 \\
\hline Widowed/Divorced & 16 & 11.43 \\
\hline \multicolumn{3}{|l|}{ Household size } \\
\hline $1-5$ & 59 & 42.14 \\
\hline $6-10$ & 65 & 46.43 \\
\hline 11 and above & 16 & 11.43 \\
\hline \multicolumn{3}{|l|}{ Mean $=7$ People } \\
\hline \multicolumn{3}{|l|}{ Primary Occupation } \\
\hline Farming & 113 & 80.71 \\
\hline Trading & 9 & 6.43 \\
\hline Civil Servant & 8 & 5.72 \\
\hline Artisans & 10 & 7.14 \\
\hline \multicolumn{3}{|l|}{ Educational Attainment } \\
\hline No formal Education & 42 & 30.0 \\
\hline Primary School & 41 & 29.28 \\
\hline Senior Secondary School & 40 & 28.57 \\
\hline Tertiary & 17 & 12.15 \\
\hline \multicolumn{3}{|l|}{ Farm Size ( Hectares) } \\
\hline$<1$ & 15 & 10.71 \\
\hline $1-5$ & 120 & 85.71 \\
\hline $6-10$ & 5 & 3.58 \\
\hline Total & 140 & 100 \\
\hline
\end{tabular}

Source: Field survey, 2014 
II: Respondents' Access to Formal Credit

\begin{tabular}{|c|c|c|}
\hline Status & Frequency & Percentage (\%) \\
\hline Accessed & 18 & 12.86 \\
\hline Did not Access & 122 & 87.14 \\
\hline Total & 18 & 100 \\
\hline
\end{tabular}

Source: Field survey, 2014

III: Financial Institutions where Respondents Had Accessed Formal Credit

\begin{tabular}{lcc}
\hline \multicolumn{1}{c}{ Financial Institution } & Frequency & Percentage (\%) \\
\hline Microfinance Banks & 13 & 92.22 \\
Commercial Bank & 2 & 11.11 \\
Bank of Agriculture & 3 & 16.67 \\
Total & 18 & 100 \\
\hline
\end{tabular}

Source: Field survey, 2014

IV: Parameter Estimates of Determinants of Access to Formal Credit by the Respondents

\begin{tabular}{lccc}
\hline \multicolumn{1}{c}{ Variable } & Coefficient & Std. Error & Z-Statistic \\
\hline Age $\left(\mathbf{X}_{1}\right)$ & 0.109206 & 0.066842 & 1.633804 \\
Gender $\left(\mathbf{X}_{\mathbf{2}}\right)$ & -3.054253 & 1.584884 & $-1.927115^{* * *}$ \\
Education level $\left(\mathbf{X}_{\mathbf{3}}\right)$ & 0.274196 & 0.132431 & $2.070473^{* *}$ \\
Distance to access point $\left(\mathbf{X}_{4}\right)$ & -0.955078 & 0.430806 & $-2.216959^{* *}$ \\
Coop. membership $\left(\mathbf{X}_{5}\right)$ & 0.010218 & 1.014701 & 0.010070 \\
Annual income $\left(\mathbf{X}_{\mathbf{6}}\right)$ & $1.89 \mathrm{E}-05$ & $6.96 \mathrm{E}-06$ & $2.713343^{*}$ \\
\hline $\mathbf{C}$ & -2.187271 & 2.955073 & -0.740175 \\
\hline
\end{tabular}

Source: Eviews 7 software $*, * *, * * *$ Significant at 1,5 and $10 \%$, respectively

V: Constraints to Accessing Formal Credit by the Respondents ( $\mathbf{N = 1 4 0 )}$

\begin{tabular}{llccccccc}
\hline S/N & \multicolumn{1}{c}{ Constraints } & SA & A & D & SD & Mean (X) & SD & Remark \\
\hline $\mathbf{1}$ & Lack of collateral security & $(67.1 \%)$ & $(32.9 \%)$ & $(0 \%)$ & $(0 \%)$ & 3.67 & 0.47 & $\mathrm{~A}$ \\
$\mathbf{2}$ & Financial illiteracy & $(62.9 \%)$ & $(35.7 \%)$ & $(1.4 \%)$ & $(0 \%)$ & 3.61 & 0.52 & $\mathrm{~A}$ \\
$\mathbf{3}$ & Complex banking procedures & $(63.6 \%)$ & $(32.1 \%)$ & $(2.9 \%)$ & $(1.4 \%)$ & 3.58 & 0.62 & $\mathrm{~A}$ \\
$\mathbf{4}$ & High Interest rates & $(64.3 \%)$ & $(35.7 \%)$ & $(0 \%)$ & $(0 \%)$ & 3.64 & 0.48 & $\mathrm{~A}$ \\
$\mathbf{5}$ & Weak farmer groups & $(48.6 \%)$ & $(44.3 \%)$ & $(4.3 \%)$ & $(2.9 \%)$ & 3.39 & 0.70 & $\mathrm{~A}$ \\
$\mathbf{6}$ & Distance to access points & $(42.9 \%)$ & $(54.3 \%)$ & $(2.9 \%)$ & $(0 \%)$ & 3.40 & 0.54 & $\mathrm{~A}$ \\
$\mathbf{7}$ & Farmer's lack of interest & $(22.1 \%)$ & $(9.3 \%)$ & $(65.7 \%)$ & $(2.9 \%)$ & 2.51 & 0.86 & $\mathrm{~A}$ \\
\hline
\end{tabular}

Source: Source: Field survey, 2014

SA = Strongly Agree, A = Agree, D = Disagree, SD = Strongly Disagree, SD = Standard Deviation.

explained by the independent variables used in the study. The significant determinants of access to formal credit by rural farmers were; age, education, distance from access point, and income level of the respondents. The finding from the study revealed that Age $\left(\mathrm{X}_{1}\right)$ has a coefficient of -3.05 and significant at $10 \%$. This implies that the probability of accessing formal production credit in the area reduces with age. This finding lends credence to the submission of Owusu (2017) who reported that age influences the probability of accessing formal credit by rural farmers in Ghana. The coefficient of years of formal education $\left(\mathrm{X}_{3}\right)$ is statistically significant at $5 \%$ level and has a positive relationship with access to formal credit. Specifically, the probability of a farmer to access loan in the area is increased by 0.274 for respondents with higher level of formal education than their counterparts with no formal education. The result corroborates those of Anyiro and Oriaku (2011), Aliero and Ibrahim (2011), Etonihu et al. (2013) and (Owusu 2017) who stated that education plays a very significant (positive) role in ensuring formal credit access by farmers. Consistent with a priori expectation, the co-efficient of distance to access point $\left(\mathrm{X}_{4}\right)$ was negative and statistically significant at $5 \%$. This implies that, respondents 
who live in remote areas may have less chances to access credit from formal financial institutions compared to their counterparts that reside closer to those institutions. The result is substantiated by Bakhshoodeh and Karami (2008) and Anyiro and Oriaku (2011) Etonihu et al. (2013) who reported significant negative relationship between distance and formal credit access among farmers in Iran and Nigeria, respectively. Level of income was positive and statistically significant at 5\% and in conformity with a priori expectations, it was positively signed. This suggests that wealthier respondents are more likely to access formal credit than others with lesser income due to their ability to provide collateral and bear costs of receiving credit. This result is consistent with those of Anyiro and Oriaku (2011), Aliero and Ibrahim (2011) who find level of income to be an important determinant of demand for credit. However, contrary to a priori expectation, the coefficient of membership of co-operatives was not significant in accessing formal credit in the area.

\section{Respondent's Constraints to Credit Acquisition}

The respondents' ability to access formal production credit in the area is constrained by some factors which are presented in Tab. 5. These constraints are common to all the formal financial institutions located in the study area. Foremost among these constraints were; lack of acceptable collateral/security $(X=3.67)$, high interest rates $(X=3.64)$, low financial literacy among the farmers $(\mathrm{X}=3.61)$, and the complex nature of banking procedures for accessing credit ( $X=3.58)$. Other problems include; weak nature of farmer groups/cooperative societies, long distance access points and total lack of interest to access formal credit for cultural and religious reasons. These outlined constraints have limited the respondents' ability to access credits that could have been used to improve their agricultural production capacities in the area.

\section{CONCLUSION}

The findings from this research revealed that age, level of education, distance to access point and income level were the main factors determining farmers' access to credit in the study area. Also, lack of collateral security, high interest rate, low financial literacy and complex banking procedures were among the major problems the respondents face in their bid to access formal credit in the area. Based on these findings, it is therefore, recommended that;

- For farmers to solve the collateral/security issue associated with credit acquisition, they should be encouraged by all rural development actors to form groups that will enable them pull resources together.

- Financial institutions should be encouraged to make their operational procedures in terms of credit administration much easier by modifying some of their operations to suite farmers, especially their eligibility criteria and other legal issues.

- Interest rate being charged by formal financial institutions in the area should be reduced to enable rural farmers to access credit facilities from the institutions.

- Adequate awareness should be created among the residents of the study area (to spur interest) on the need and processes of acquiring formal production credit facilities from Banks.

\section{Acknowledgment}

The authors sincerely appreciate the staff of Community Development Office of the Yola South Local Government Area and those Federal Department of Agriculture Yola for their assistance in sampling the rural communities and also data collection.

\section{REFERENCES}

ADEBAYO, A. A. 1999. Climate, Sunshine, Temperature, Evaporation and Relative Humidity. In: ADEBAYO, A. A. and TUKUR, A. L. (Eds.). Adamawa State in Maps. Yola, Nigeria: Paraclette Publishers, pp. 20-22.

ADEBAYO, A. A., ONU, J. I., ADEBAYO, E. F. and ANYANWU, S. O. 2012. Farmers' Awareness, Vulnerability and Adaptation to Climate Change in Adamawa State, Nigeria. British journal of arts and social sciences, 9(2): 104-115.

ADEPOJU, A. O. and YUSUF, S. A. 2012. Poverty and Vulnerability in Rural South-West Nigeria. ARPN J. Agric. Biolog. Sci., 7(6): 430-437.

AIGBOKHAN, B. E. and ASEMOTA, A. E. 2011. An Assessment of Microfinance as a Tool for Poverty Reduction and Social Capital Formation: Evidence on Nigeria. Global Journal of Finance and Banking Issues, 5(5): 38-48.

AKINBODE, S. O. 2013. Access to Credit: Implication for Sustainable Rice Production in Nigeria. Journal of Sustainable Development in Africa, 15(1): 13-30.

ALIERO, H. M. and IBRAHIM, S. S. 2011. An analysis of farmers' access to formal credit in the rural areas of Nigeria. African Journal of Agricultural Research, 6(17): 1-6. 
ANANG, B. T., BÄCKMAN, S. and SIPILÄINEN, T. 2016. Agricultural microcredit and technical efficiency: The case of smallholder rice farmers in Northern Ghana. Journal of Agriculture and Rural Development in the Tropics and Subtropics, 117(2): 189-202.

ANYIRO, C. O. and ORIAKU, B. N. 2011. Access to and Investment of Formal Micro Credit by Small Holder Farmers in Abia state, Nigeria. A case study of ABSU micro finance bank, uturu. The Journal of Agricultural Sciences, 6(2): 69-76.

AWOTIDE, B. A., ABDOUlaye, T., ALENE, A. and MANYONG, V. M. 2015. Impact of Access to Credit on Agricultural Productivity: Evidence from Smallholder Cassava Farmers in Nigeria. A Contributed paper Prepared for Oral Presentation at the International Conference of Agricultural Economists (ICAE) Milan, Italy, August 9-14.

AYAZ, S., ANWAR, S., SIAL, M. H. and HUSSAIN, Z. 2011. Role of Agricultural Credit on Production Efficiency of Farming Sector in Pakistan - A Data Envelopment Analysis. Pakistan Journal of Life and Social Sciences, 9(1): 38-44.

BADIRU, I. O. 2010. Review of Small Farmers Access to Agricultural Credit in Nigeria. International Food Policy Research Institute. Series No. 25, pp.1-6.

BAFFOE, G., MATSUDA, H., MASAFUNII, N. and AKIYAMA, T. 2015. The dynamics of rural credit and its impact on agricultural productivity: an empirical study in Rural Ghana. OIDA International Journal of Sustainable Development, 7(5): 19-34.

BAKHSHOODEH, M., and KARAMI, A. 2008. Determinants of Poor Accessibility to Microcredits in rural Iran. In: International Conference on Applied Economics. Department of International Trade, Kastoria Campus, TEI of Western Macedonia.

BASHIR, M. K., MEHMOOD, Y. and HASSAN, S. 2010. Impact of Agricultural Credit on Productivity of Wheat Crop: Evidence from Lahore, Punjab, Pakistan. Pak. J. Agri. Sci., Vol., 47(4): 405-409.

CHANDIO, A. A., YUANSHENG, J., SAHITO, J. G. M. and LARIK, S. A . 2016. Impact of formal credit on agricultural output: Evidence from Pakistan. African Journal of Business Management, 10(8): 162-168.

CHAOVANAPOONPHOL, Y., BATTESE, G. E. and CHANG, H. 2005. The impact of rural financial services on the technical efficiency of rice farmers in the Upper North of Thailand. Contributed Paper at the Annual Conference of the Australian Agricultural and Resource Economics Society at Coffs Harbour, 9-11 February.

EDIOMO-UBONG, E. N. and IBORO, E. N. 2010. Micro-Credit Programme and Poverty Alleviation in Rural Nigeria: A Case Study of Akwa Ibom State. International Journal of Economic Development Research and Investment, $1(2$ \& 3): 168-180.

EFINA. 2014. Access to Financial Service in Nigeria Survey. [Online]. Available at: www.efina.org.ng/our-work/ research/access-to-financial-services-in-nigeria-survey/ [Accessed: 2016, June 27].

ENYIM, O.B., EWNO, E. N. and OKORO, O. T. 2013. Banking sector credit and the performance of the agricultural sector in Nigeria. European Journal of Scientific Research, 23(2): 35-55.

ETONIHU, K. I., RAHMAN, S. A. and USMAN, S. 2013. Determinants of Access to Agricultural Credit among Crop Farmers in a Farming Community of Nasarawa State, Nigeria. Journal of Development and Agricultural Economics, 5(5): 192-196.

FEDER, G., LAU, L. J., LIN, L. Y. and LUO, X. 1990. The relationship between credit and productivity in Chinese agriculture: A microeconomic model of disequilibrium. American Journal of Agricultural Economics, 72(5): 1151-1157.

FOLTZ, J. 2004. Credit market constraints and profitability in Tunisian agriculture. PhD Thesis. University of Wisconsin, USA.

GHATE, P. B. 1992. Interaction Between the Formal and Informal Financial Sectors: The Asian Experience. World Development, 1(14): 28-36.

IJERE, M. O. 1998. Agricultural Credit and Economic Development. In: IJERE, M. O. and OKORIE, A. (Eds.). Readings in Agricultural Finance. Longman, Lagos, pp. 4-9.

KASHULIZA, A.K., HELLA, P., MAGAYANE, F. F. and MVENA,Z. S. K. 1998. The role of Informal and Semi-formal Finance in Poverty Alleviation in Tanzania: Results of a field study in two regions of REPOA. Research Report No 98.1.

NATIONAL BUREAU OF STATISTICS. 2014. National Living Standard Survey. Abuja: National Bureau of Statistics.

NATIONAL POPULATION COMMISSION. 2006. Human population figures of 2006 Census in Nigeria. Lagos: Official Gazette, Vol. 94.

NIMOH, F., KWASI, A. and THAM-AGYEKUM, E. K. 2011. Effect of formal credit on the performance of the poultry industry: The case of urban and peri-urban Kumasi in the Ashanti Region. Journal of Development and Agricultural Economics, 3(6): 236-240.

NWANKWO, O. 2013. Agricultural Financing in Nigeria: An Empirical Study of Nigerian Agricultural Co-operative and Rural Development Bank (NACRDB): 19902010. Journal of Management Research, 5(2): 28-44.

ODOEMENEM, I. U. and OBINNE, C. P. O. 2010. Assessing the Factors Influencing the Utilization of improved Cereal Crop Production Technologies by Small Scale Farmers in Nigeria. Indian Journal of Science and Technology, 3(1): 180-183. 
OWOSU, S. 2017. Effect of Access to Credit on Agricultural Productivity: Evidence from Cassava Farmers in the Afigya-Kwabre District of Ghana. International Journal of Innovative Research in Social Sciences $\sigma$ Strategic Management Techniques, 4(2): 55-67.

World Bank. 2014. Data.worldbank.org/indicator/sp.RuR.ToTL. Retrieved $13^{\text {th }}$ April, 2015. 